IDEA - Studia nad strukturą i rozwojem pojęć filozoficznych $\mathrm{XXIX/1}$

Białystok 2017

\title{
Paulina Ambroży
}

(Poznań)

\section{“IN YOUR SYNTHESIS THE SIGNAL CONDENSES": ADAM DICKINSON'S POLYMERS AND KACPER BARTCZAK'S ORGANIC POEMS AND THE PLASTIC POETICS OF THE CONTEMPORARY ORGANIC POEM}

In his Introduction to an interdisciplinary study of organicity, titled $A p$ proaches to Organic Form: Permutations in Science and Culture, Frederick Burwick problematizes "the inherent difficulty in adequately defining 'organic form": "Attempts to define a structure, shape, or form as organic inevitably lapse into the shoddy logic of petitio principi, or post hoc, propter hoc. Because it emerges through process, organic form resists definitions which try to identify as if it were fixed and definite. Thus it is more apt to describe forming and shaping, rather than the form or shape"1. This difficulty is perceptible also in diverse metaphorical, aesthetic and philosophical adaptations and reformulations of the concept, from Plato's idea of organic unity of the form, through Kant's use of the term to discuss the inherent and autonomous structure of the mind and its aesthetic creations, to the Romantic philosophers' and poets' absorption of the concept as a metaphor for aesthetic freedom and the reciprocity of the form and content ${ }^{2}$. Frequently juxtaposed with mechanistic and mathematical views

${ }^{1}$ F. Burwick. Introduction, in: In Approaches to Organic Form: Permutations in Science and Culture. Dordrecht D. Reidel Publishing Company, 1987, p. ix.

${ }^{2}$ Ibid., p. ix. 
which deal with artifice, imposed but efficient and intelligible designs, the organic form has become a capacious trope appropriated in religious, social, aesthetic and philosophical contexts to describe dynamism, variety, complexity, harmony, beauty, mystery and fullness of creation.

The goal of my study is to explore contemporary poets' creative grappling with the concept of organic form. For my analysis, I have selected two innovative volumes of poetry: Kacper Bartczak's most recent collection Wiersze organiczne [Organic poems] (2015) and Adam Dickinson's The Polymers (2013). Interestingly, in their explorations both poets employ plastic as a poetic medium, which, as I shall argue, has a rich deconstructive potential, as its nature, forms as well as processes exhibit a tension between the natural and the artificial. Plastic incorporates the inherent paradoxes of organic form in which the notions of completeness, perfection and unity are interwoven with their opposites - temporality, process, contingency and becoming. This doubleness, as evidenced in Bartczak's and Dickinson's poems, proves particularly productive for addressing the aesthetic, ideological and epistemological challenges of contemporaneity.

Poetry, as famously argued by Samuel Taylor Coleridge is "opposed to science" and every work of genius creates "its own organic form" ${ }^{3}$. Plastic, as a synthetic form produced out of alliance between science and biology, serves Bartczak and Dickinson to question this opposition, showing their dialogue with the Romantic organicist ideal. At once a product of science and nature, plastic seems indeed a fitting metaphor and material for their revisionist quest for a more capacious definition of a poem-as-organism.

The ambiguous and disruptive potential of plastic has been pointed out by Roland Barthes in Mythologies - the text both poets invoke in their volumes. Barthes interrogates the "negative reality" of the material. "In the hierarchy of the major poetic substances", plastic, the philosopher argues, is "a disgraced material", a mere substitution for the original, "something powerless ever to achieve the triumphant smoothness of Nature"4. "[M]ore than a substance," the philosopher claims however, "plastic is the very idea of its infinite transformation; as

${ }^{3}$ Samuel Taylor Coleridge. "Shakespeare, with Introductory Matter on Poetry, the Drama, and the Stage"; in: Henry Nelson Coleridge (ed.) The Literary Remains of Samuel Taylor Coleridge. Vol. II. London: Pickering, 1836, p. 7.

${ }^{4}$ R. Barthes, Mythologies" p. 98. 


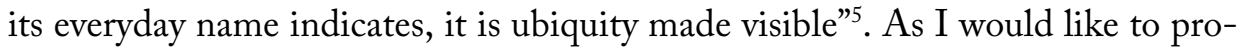
pose, Adam Dickinson's The Polymers and Kacper Bartczak's Wiersze organiczne [Organic poems] - take up Barthes' challenge to engage with the contemporary mythology of plastic and to reclaim for poetry the infinitely transformative potential of the synthetic form.

I would like to start my analysis with the opening of Adam Dickinson's The Polymers - the prose poem titled "Cellophane", printed significantly on a plastic page and written in the form of a scholarly abstract. I had an opportunity to ask the poet himself about his concept of the organic form, and here is what he wrote:

The notion of organicity is of great interest to me because in the Capitalist Anthropocene it is no longer possible to separate the "natural" from the "cultural" or the emergent and intuited form from one already affected or determined by material and social circumstances. Plastic is a particularly interesting example because it is the epitome of artificiality and yet its very materiality is a function of the kind of polymerization processes intrinsic to organic life (DNA, proteins, the hair on our heads, etc.). Plastic also requires that we think of writing in more expansive ways, in ways that blur the boundaries between the organic and the inorganic, or between nature and culture. ${ }^{6}$

The poem best explains and addresses the complex structural make-up of plastic materials, prefiguring also the structural complexity as well as metacritical thrust of Dickinson's volume:

Polymers are giant molecules composed of numerous repeating parts. As long chains, they form the basis of both synthetic and natural plastics - the structures of the human brain, skin, hair, as well as DNA are all composed of polymers. As prevalent as polymers are biologically, plastic, as a cultural and industrial commodity, is similarly omnipresent. Its ubiquity, however, marks a curious contradictory tension: plastic is at once outmoded and futuristic, colloquial and scientific, a polluting substance that is also intimately associated with our lives. The origins of plastic, as an industrial material, have extended and continue to extend out of attempts to mimic or substitute for things in the natural world. Therefore, plastic marks both the presence and the absence of natural objects, embodying tension be-

\footnotetext{
${ }^{5}$ Ibid., p. 97.

${ }^{6}$ A. Dickinson, an email letter to Paulina Ambroży, September 20, 2016.
} 
tween the literal and the metaphorical, as it recreates the world as an alternate or translated reality. ${ }^{7}$

My goal is to address the tensions inherent in the material and follow selected aspects of Dickinson's and Bartczak's engagement with its biosemiotics. What I would like to show in particular is how it "translates" into innovative forms of their poems. As a consequence of this formal emphasis, I am deliberately bracketing the cultural backgrounds of the poets ${ }^{8}$, as my primary focus will be their shared interrogatory as well as rhetorical sensibility and the ways in which they probe forms and limits of poetic communication.

In an interview, Bartczak speaks of his notion of the poetic form as inclusive, dynamic and open:

Myślę o poetyce pojemnej, która weźmie na siebie zadanie anulowania niedobrych schematów i dystynkcji, którymi żyła, nadal żyje, nasza kultura: ciało/umysł, język/ciało, język/rzeczywistość, etc. O takiej poetyce, która będzie nadążać za dynamiką naszej wymienności ze światem, naszych płynnych złożeń i rozłożeń. O takiej poetyce wreszcie, która, nie zaprzęgając poezji do żadnych użyć wymiernych, pomoże jednak ludziom się odnajdować w ich własnej złożoności, w której sfery języka, psychiki, estetyki i somatyki będą się wspomagać, wzajemnie aktywować. ${ }^{9}$

[I am thinking of an inclusive poetics which will take up the task of invaliding inadequate schemes and differentiations which have informed our culture: body/mind, language/body, language/reality, etc. Of the poetics which would match the dynamics of our interconnectedness with the world, of our fluid integrations and disintegrations. And finally, of that kind of poetics which, without claiming poetry for any utilitarian use, would help people see themselves in their

${ }^{7}$ A. Dickinson. The Polymers. Toronto: Anansi, 2013, np.

${ }^{8}$ It should be noted, however, that Adam Dickinson's poetry is more consistently committed to the ecocritical and biosemiotical currents in contemporary Canadian poetry. His previous volumes Cartography and Walking (2002) and Kingdom, Phylum (2006) similarly stem from the poet's deep and sustained interest in the intersections between science and poetry. In both volumes, the poet the poet employs innovative modes of writing to confront and revise the existing conceptualizations of nature-culture divide and revise North-American mythologies of the wilderness.

${ }^{9}$ J. Skurtys and R. Kaczmarski. "Poezja nie jest już liryką". An Interview with Kacper Bartczak. BiBLioteka: Magazyn literacki. http://www.biuroliterackie.p1/biblioteka/wywiady/poezjanie-jest-juz-liryka? 
own complexity, the poetics in which the spheres of language, psyche, aesthetics and somatics will cooperate and activate one another. $]^{10}$.

My contention is that Bartczak's Organic poems, and also Dickinson's The Polymers, use the tension between biological and synthetic forms to create such an inclusive mode of writing - a flexible and absorptive poetics capable of bending conventions and forms to undo binary structures of thought and to create a non-anthropocentric inter-connective net of aesthetic, linguistic and somatic levels of experience.

\section{1. “Że z plastiku jesteś i w plastic / w nim się zapowiesz"11 [That you are made of plastic / and unto plastic / in it you will announce yourself']: Kacper Bartczak's Organic Forms}

Plastic, Roland Barthes contends, is "in essence the stuff of alchemy" (98), a proof for a possible miraculous "transmutation of matter" 12 "At one end, raw, telluric matter," the French philosopher observes further on, "at the other, the finished, human object; and between these two extremes, nothing; nothing but a transit"13. This wondrous "alchemy" and transformational potential of plastic is mimicked and probed in Kacper Bartczak's Wiersze organiczne. The poet is interested in the idea of "transit", and his volume takes us into the liminal spaces and processes between the self and the other, the subject and object, the raw matter of reality and its diverse organic and mechanical languages. In his inquiry, the poet foregrounds processes of mediation, transmission and communication, with their elements of unpredictability and potential for a suspension, derailing or dispersal of meaning. In the poem "Polimer i nic" [Polymer and nothing], the poet equates plastic with the world, for it proves the most flexible medium capable of building, structuring and simulating realities:

${ }^{10}$ All the translations from Polish, unless otherwise indicated, are mine.

${ }^{11}$ The quote comes from the opening verses of Bartczak's poem "Polimer i nic" [Polymer and nothing], Wiersze organiczne, Łódź: Dom Twórców Literatury, 2015, p. 29.

${ }^{12}$ R. Barthes, op. cit., 98.

${ }^{13}$ Ibid., 98. 
najbardziej jest plastik

tak się świat

że nie drewno nie gnejs

nie sól nawet nie węgiel tylko plastik

mówi jak jest że trzeba mówić

jak jest czyli plastik

Że z plastiku jesteś i w plastik

$\mathrm{W}$ nim się zapowiesz ${ }^{14}$ [plastic the fullest of being]

[the world is such]

[that not wood not gneiss]

[not salt not even coal but plastic]

[he says how it is speaks the need

to say]

[what it's all like plastic that is]

Plastic becomes for the poet at once a body and language that is "the fullest being" which "speaks" and "says how it is", not only by providing patterns and materials for simulacra of reality ["what it's all like plastic that is"], but also by inspiring poetic paradigms of metonymic and metaphoric transfer. One of the metonymic "transfers" is suggested by the "plasticity" of syntax which in the opening line "najbardziej jest plastik", is bent to the point of breaking to match the material's flexibility. In the stanzas that follow, the syntax is used to "deconstruct" plastic's ersatz and thus inferior status through a series of negations "that not wood not gneiss/ not salt not even coal but plastic" - which function "collaterally"15 (Grimes, 1975), intensifying our cognitive engagement with the illocutionary force and epistemic modality underlying the whole statement. The communicative blockage which this negative series introduces into this argument reflects Bartczak's need to question the epistemic distinction between the natural and the artificial and to point to a dynamic relation between our binary categorizations of reality. No wonder than that his organic poems will thus most naturally and fully "announce" themselves in plastic.

This critical revaluation and destabilization of the opposition between natural and synthetic forms is visible in "Pieśń tworzyw sztucznych" [The song of

${ }^{14}$ K. Bartczak, "Polimer i nic", Wiersze organiczne, op. cit., p. 29. English translation of the poem by Kacper Bartczak, Paulina Ambroży and Marit McArthur.

${ }^{15}$ J. E. Grimes. The Thread of Discourse. The Hague: Mouton, 1975, p. 66. 
synthetic forms], the opening poem from Bartczak's volume in which the plastic "interplay" of "natural" and "mechanical" discourses is "activated". The first lines significantly define poetry as "an area of maximum labor" and "an area of mineral labor"- an environment suggestive of both controlled and conscious activity and natural and thus unpredictable, transformational processes:

Tyś jest obszar pracy maksymalnej

[In you the zone of maximum labor] obszar opłat kompresji albumin i zgliszcz

[the toll zone, compressed protein and dust]

Tyś jest obszar pracy mineralnej

[In you the zone of mineral labor]

W tobie łupki pokonują barierę wchodzą w wartość papieru

[in you shales break barriers enter paper value]

Tyś jest miejsce zarządzania spalaniem to miejsce ten czas

[you are the place of combustion management this place this time]

wzywasz do sieci światłowodem stajesz u bram

[you summon to the net the light fibers approach the gates]

Sposobisz arktyczne spedycje

[You hasten Arctic dispatches]

wzywasz rosę różę na kopalny punkt

[you summon dew a rose to a mining point ]

Dajesz się mocno we znaki gdy propagujesz piękno

[You leave a mark when you propagate beauty]

srebrną rosę światłowodem przewodzisz w wartość papieru.

[you conduct dew through fiber optics into paper value ]

Wszczynasz śpiew w żużlach i żywice tężeją w podanym metrum

[In you singing commences in slags and resins congeal in set meter] grafen pokonuje barierę wiersza własnego wchodzi do globalnej gry [graphene breaks the barrier of the poem of its own enters global game]

Ślesz się pod ziemię pod lód w ogniste oblicze

[You expedite yourself into ice into the face of fire]

w sztab dyrektorów radę nadzorczą komitet koronę rdzeń

[into the board of directors supervisory committee the crown the core]

W twojej osmozie migrują paliwa aktywują słońca

[In your osmosis fuel migrates activates suns] 
wchodzą protokoły miazgi

[protocols rise and pulps]

W twojej syntezie kondensuje się sygnał

[In your synthesis the signal condenses]

zadany peleng zarządza ludzkim miałem

[the target bearing manages human dust]

Spokojni odprężeni w podanym metrum

[Tranquil relaxed in the set meter]

podążamy na miejsce zbiórki to miejsce ten czas

[we proceed to the meeting point this place this time]

Powiedzcie wierszowi że pleciemy ekrany ze światła i strun

[Tell the poem that we weave screens of light and strings]

wypatrujemy wkładu prosimy poręki porady

[we await input we ask of surety advice]

Przeniknięci wierszem stanowimy tworzywo sprasowane na wieki

[Suffused by the poem we constitute material compressed for eternity]

w obszar królestwa odwleczeni tam też czytamy memo przesłanie

[deferred inside the kingdom thereby we read a memo a message]

Wierzymy żeśmy mu jedyną ofertą w niego przenosimy poznanie

[we trust we are the only offering in it we locate cognition]

byśmy przesłali materiał na kurs arkusz i miał

[so that we send the material for course sheet and dust] ${ }^{16}$

This curious "song of synthetic forms" pulls us into a highly absorptive and "polluted" habitat of Bartczak's discursive imagination which, as discover, draws on infinite external and internal stimuli and diverse and vocabularies. These "enter" the poem and trigger off a chain of "alchemic" or, better, "chemical" reactions and transformations. There is a lot going on in this piece as the dizzying and "plastic" activity of language continuously questions the boundaries between organic and artificial realms, problematizing the very structure of communica-

${ }^{16}$ K. Bartczak, "Pieśń tworzyw sztucznych" [The Song of Synthetic Forms], Wiersze organiczne, op. cit., p. 5. [English translation of the poem by Kacper Bartczak, Marit MacArthur, Paulina Ambroży]. 
tion. The poem, equated at once with organic and mechanical forces, progresses self-reflexively and performatively, with each new verse serving as a comment on biological and communicative environments, processes, "transmissions" of signs happening in this "area of maximum labor". From the busy laboratory of the text, for there is no clear agency behind the relentless activity of language, the words emerge at once familiar and strangely alien, as they both gesture towards recognizable "systems" of interpretation and iterative social behaviors (as navigation, global economy, or technological transmission of data) and break through them. The encounters of the linguistic "polymers" in the text are violent and tend to overspill meaning, as they undergo compression, collusion, combustion, congealing, migration, blockage, synthesis, condensation, and osmotic exchange. As if wishing to expose potential accidents happening to "its telluric matter" "in transit", Bartczak's song colludes disparate lexicons (as "slags which congeal in set meter" or "target bearing" which "manages human dust"), images (as "graphene" which "breaks the barrier of the poem"), registers and tones (e.g. the high-toned address of "tys jest /thou art" which is linked with the discourses of geological and industrial "laboring"). Those collusions and collisions recreate a dynamic, curiously symbiotic but ultimately unpredictable texture of communication in which thought and words encounter, travel and break through various materials, "gates" and "barriers". In the integrative-disintegrative movement of the "song", the materials are continuously translated and retranslated into new realities and shapes which begin as solid and concrete materials of empirical reality (e.g. shales and slag) only to turn into more elusive ontologies of dew, ice, fire, light, pulp, fibers, and dust (some of them quite romantically-flavored, as in the cluster "we weave screens of light and strings"). The emergent vision, (if we can call it "a vision" as it determinately resists closure, systematic anchoring and anthropocentric perspective), which draws parallels between geological landscape, cognitive mindscape and the processes of poeisis, carries us in unexpected directions, where the poem's "body" flaunts a complexity comparable to that of the earth's geological and biological processes and layers.

Taking his cue from Barthes' urge to see beyond the negative reality of plastic and embrace its metaphorical power, Bartczak uses the trope of synthetic form to ask questions about the nature of organicity itself, especially as it relates 
to poetry and communication. The poem, which Bartczak theorizes elsewhere ${ }^{17}$ as a "living" and "talking organism", at once tries to order and contain the unstoppable "plenitude of language", as it intercepts and ingests discourses of geology, physics and biology (as "mineral labor", "proteins" "mining point" "compression", "migrating fuels" which "activate suns", "shales", "resins", "slags", "ice", "crown", "core", "graphene"), technology (optical fibers, screen, net, compressed material, the signal which "condenses"), economy (toll zone, paper value, surety, board of directors, global game, management), music (song, strings, the set meter), shipping, transmission and navigation (expedite, hasten Arctic dispatches, approaches gate) and lets it free through the collusions and crosspollutions of their contingent boundaries.

The collusion of clichés from disparate discursive realms, as in "protocols rise and pulps" or "you expedite yourself ... into board of directors", opens up new communicative levels of the text which expose at once connectivity and contingency of semantic constructs and contexts, invalidating the boundaries between linguistic naturalness and artifice. When "dispatched" and in "transit" from one protocol to another, the words leak their compressed "pollutions", artificialities and fragile illusions of wholeness. "In thy synthesis the signal condenses", we can read in the poem, and indeed, the condensation leads the reader towards a realization of poetry's participation in a larger discursive environment where the gap between nature and culture closes and where the meaning seems to be simultaneously upheld by the constructed "protocols" and undone by their deconstructive and osmotic collusions. The resulting habitat seems to be feeding off the very "organic" energy of language which refuses to rest in appropriated and automated styles and tropes. This continuous activity of transformation within "the bios" of the poem from concrete images to self-aware metaphor determinately subverts the Romantic concept of organic form as an aesthetic wholeness with metaphysical grounding, replacing it with "global games" of deferred and non-conclusive mediations.

"We await input we ask of surety advice", the perspective shifts in the second part of the poem from the apostrophic "you" to a mysteriously and uncomfortably inclusive "we", and the reader cannot but feel "included" in or, better, "navigated" into the hope for "surety advice". The "surety", as we can predict,

${ }^{17}$ See K. Bartczak, "Bodies that Sing: Somaesthetics in the American Poetic Tradition," Pragmatism Today: The Journal of the Central European Pragmatist Forum, 3.(2), 2012, pp. 29-39. 
will not hold as this centerless mad laboratory of discourses, like chemical or biological processes, carries the anguish of accidents, errors, and dispersals. The only ruler of this "kingdom", as this poem is ironically called in the second part of the poem, is language in its potentiality, building its force on the slippery and shifting ground of rhetorical displacements.

\section{2. "Hello From Inside the Albatross"18: Adam Dickinson's Polymeric Imagination}

Adam Dickinson's Polymers likewise probe the usability of plastics in search for a fresh poetic form and a more inclusive discourse. Moving away from the natural world dominating his previous volume Kingdom, Phylum (2006), the poet ventures into what he himself calls "an extraordinary science project performed at the nexus of chemistry and poetry"19 in which he looks into the industrial and micromolecular world of plastics. As synthetic materials in Bartczak's volume, the eponymous polymers are treated by the Canadian poet as a metaphor of a ubiquitous but alien, quasi-cabalistic language that shapes and permeates our reality ${ }^{20}$. "Plastic", the poet himself explains, "is an emergent expression of the petrochemical age. Its pervasiveness, as a tool and a physical and chemical pollution, makes it an organizing principle (a poetics) for recurring forms of language, for obsessive conduct, and for the macromolecular arrangements of people and waste in geopolitical space"21.

In the already quoted email, the poet further clarifies the conceptual and discursive complexity of his central metaphor:

When it comes to plastic, organicity presented me with paradoxical compositional imperatives in The Polymers. I was definitely interested in developing forms adequate to the subject matter - I returned often to the challenge of how best to enact a polymeric poetics (in this way, "organic form," as a compositional disposition

${ }^{18}$ The quote comes from the opening of A. Dickinson's poem "Hail", The Polymers, Toronto: Anansi, 2013, p. 7.

${ }^{19}$ A. Dickinson, The Polymers, op. cit., back cover.

20 R. Whyatt, Review of Adam Dickinson's Polymers. Lemon Hound 5 (2013). http://lemonhound.com/2013/06/08/rachael-wyatt-on-adam-dickinsons-the-polymers/

${ }^{21}$ A. Dickinson, "Cellophane", The Polymers, op. cit., np. 
whereby form emerges from the subject matter, was part of my thinking). However, as a function of doing this I also felt it necessary to invite contingencies into the text through the imposition of "mechanical" compositional constraints concerned with repetition, iteration, accretion, and accumulation. ${ }^{22}$

Emulating the transformational variety of polymeric structures, the poet creates or borrows various protocols for exchange, synthesis and symbiosis of science and poetic discourse. The scientific paradigms include the table of contents for each section of the poem which is designed to mimic the structure of the seven principal polymers "presiding over" respective parts. (Fig. 1).

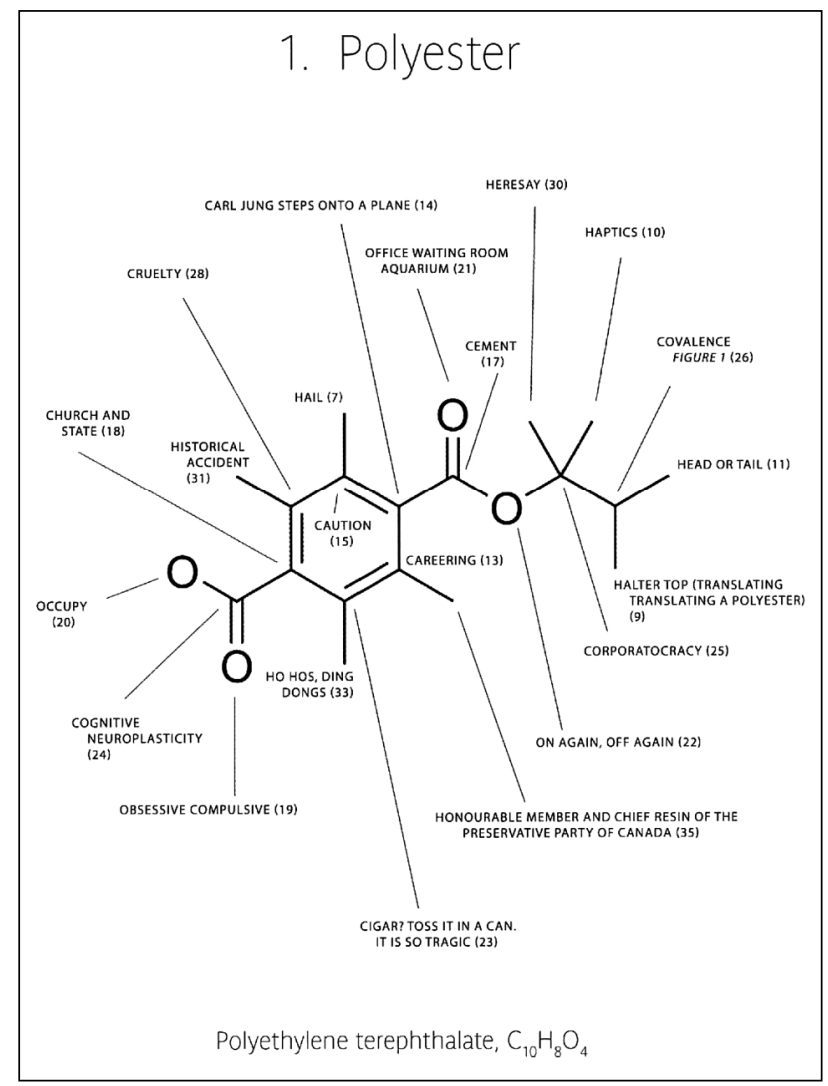

Fig. 1. Adam Dickinson. The Polymers. Toronto: House of Anansi, 2013. Sample Content Page

${ }^{\circledR}$ Copyright 2017 Courtesy of Adam Dickinson and House of Anansi

${ }^{22}$ A. Dickinson, a private email to the author, September 20, 2016. 
The molecular pattern of each polymer dictates also the first letters of the poems' titles (so all the poems begin either with the letter $\mathrm{C}, \mathrm{H}$, or $\mathrm{O}$ to recreate the qualitative make-up of carbons, hydrogen and oxygen constituting the said polymer). The scientific rhetoric drives also the opening piece written in the form of a scholarly abstract ("Cellophane"), the humorous "Index to Modern Plastics" closing the volume, and the mock-appendix of "Materials and Methods". The same effect is achieved by the poet in the playful graphic and photographic representations of polymeric structures in such poems as "Occupy", "Che Guevara Delighted to See His Face on the Breasts of So Many Beautiful Women" or "Chewing Gum") (Fig. 2), as well as in the experimental pieces which fuse pictorial and verbal signs (e.g. "Resin Identification Code", "Covalence figure 1") (Fig. 3 and 4).

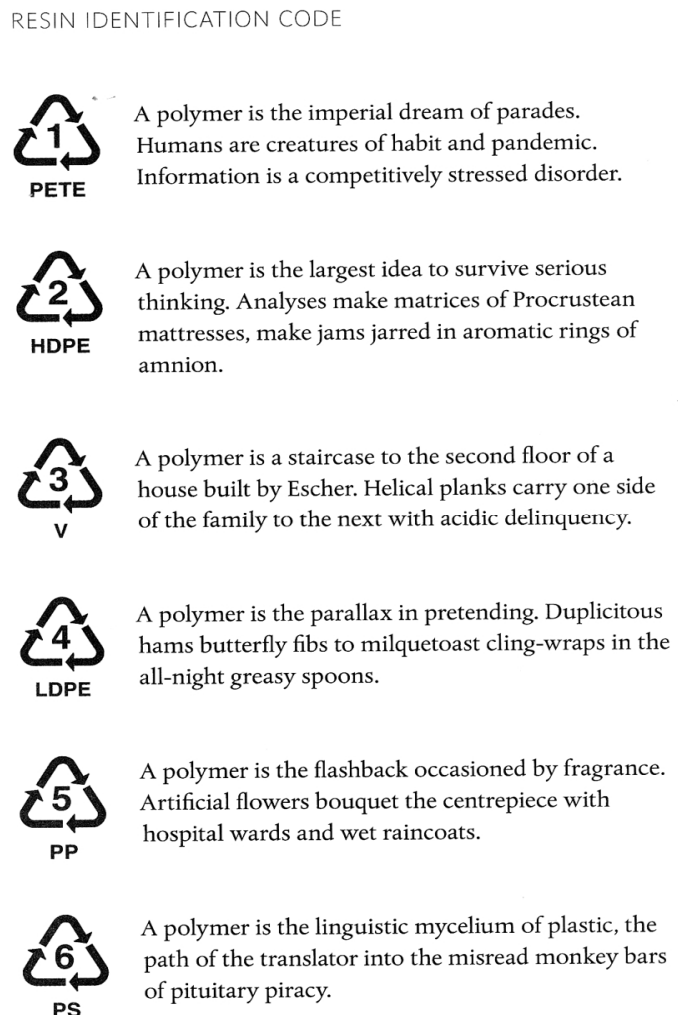

A polymer is a staircase to the second floor of a house built by Escher. Helical planks carry one side of the family to the next with acidic delinquency.

A polymer is the parallax in pretending. Duplicitous hams butterfly fibs to milquetoast cling-wraps in the all-night greasy spoons.

A polymer is the flashback occasioned by fragrance. Artificial flowers bouquet the centrepiece with hospital wards and wet raincoats.

A polymer is the linguistic mycelium of plastic, the path of the translator into the misread monkey bars of pituitary piracy.

Fig. 2. Adam Dickinson The Poem "Occupy"

The Polymers. (p. 20). Toronto: House of Anansi, 2013.

${ }^{\circledR}$ Copyright 2017 Courtesy of Adam Dickinson and House of Anansi 


\section{CHEWING GUM}

Derived from vinyl acetate monomer

(VAM)

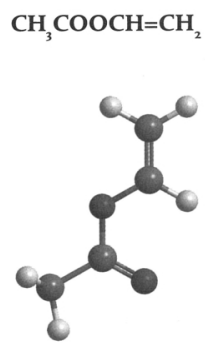

After Chewing

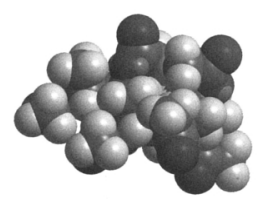

Suppliers

Celanese Corporation, Dallas, TX, USA

Sinopec Group, Beijing, China

LyondellBasell Industries, Rotterdam, Netherlands

Fig. 3. Adam Dickinson. The Poem "Chewing Gum" The Polymers. (p. 48). Toronto: House of Anansi, 2013. ${ }^{\circledR}$ Copyright 2017 Courtesy of Adam Dickinson and House of Anansi

However, the scientific codes are frequently fractured by the colloquial diction in "Ho, Hos, Ding Dongs", and "Holy Shit, Ruby, I Love You"; but they can also be fused and intertwined, as in such pieces as "Resin Identification Code," "Common Polymer Shared By Two or More Words in a Different Language", "Careering", or "Cruelty", in which the language of chemistry and the vernacular go hand in hand, sometimes to the effect of uncanny naturalness, as in the tongue-twisting sentence "Analyses make matrices of Procrustean mattresses, make jams jarred in aromatic rings of amnion" ${ }^{23}$, or the playful phrase

\footnotetext{
${ }^{23}$ A. Dickinson, "Resin Identification Code", in: The Polymers, op. cit., p. 2.
} 
"Helical planks carry one side of the family to the next with acidic delinquency"24. $^{24}$.

There are also procedural poems, in the manner of the Oulipo's algorithmbased experimentation, in which language is controlled by a pre-established pattern, as in "Coca-Cola Dasani" which uses a found material - a label from a soft drink - in which words have been re-ordered alphabetically, or "Obsessive Compulsive", which is built of various combinations of the words "people" and "resin". Another interesting experiment is the poem "Halter Top (Translating Translating a Polyester)" which echoes bp Nichols' poem "Translating Translating Apollinaire". Here one of the polymers "Polyethylene terephthalate" is playfully translated into a witty alliterative lines and surrealist images such as "Let the python plot the thorn / Let the hornet paper the tree / Let pollen apron the path to the pharaoh" 25 . The mechanics of "Careering" is playfully rendered by the graphic layout of the poem mimicking the ladder-structure of social advancement, so is the forcefully justified margin of "Hydroelectric Wax Museum" which performs and ironically extolls the benefits of "the line-up".

The thematic content of Dickinson's poems is equally "complexified", for like Bartczak's poems, it covers biological, chemical, social, economic and poetic concerns, as if to match the ubiquity interconnectivity of polymeric forms. "Hail", the poem that lends the title to this section, prefigures this complexity, as it is written from the perspective of the polymers themselves. Here polymers are subjects rather than objects, since they "introduce" themselves as building and "polluting" blocks of various animal as well as artificial bodies:

\author{
Hello from inside \\ the albatross \\ with a windproof lighter \\ and Japanese police tape. \\ Hello from staghorn \\ coral beds \\ waving at the beaked whale's \\ mistake \\ all six square meters \\ of fertilizer bags
}

\footnotetext{
${ }^{24}$ Ibid., p. 2.

${ }^{25}$ A. Dickinson, The Polymers, op. cit., p. 9.
} 
Hello from can-opened
delta gators,
taxidermied
with twenty-five grocery sacks
and a Halloween Hulk mask. ${ }^{26}$

This playful series of "polymeric" appellations display the ubiquity and biodiversity of resins, which can be found in inside albatross' and camel's stomachs, in coral beds, Japanese police tape, fertilizer bags, grocery sacks, chewing gum and a Halloween mask. Dickinson wallows in this ubiquity and "the glimmer of plastics' metaphorical power" ${ }^{27}$, as his poems keep morphing from biological to social, scientific, economic, ecological and linguistic backdrops. As in Bartczak's volume, the unexpected insights resulting from this practice shows the molecules' "connective" capacity to interrelate, pollute and permeate disparate environments and social behaviors. In the poem "Resin Identification Code", polymers are introduced through their international coding system which allows their identification within the content of recycled materials. (Fig. 4).<smiles>CNCCCCCCC(=O)NCCCCCC(C)=O</smiles>

Fig. 4. Adam Dickinson. Fragment of the Poem "Resin Identification Code". The Polymers. (p. 2)

Toronto: House of Anansi, 2013.

${ }^{\circledR}$ Copyright 2017 Courtesy of Adam Dickinson and House of Anansi

The poet offers a mock-explication for each code, exploring poetic potential of breaking the discursive integrity of the coding system. Polymers become here "the imperial dream of parades", "the largest idea to survive serious thinking", "the parallax in pretending", "the flashback occasioned by fragrance", "the linguistic mycelium of plastic" 2 . The sequencing and repeatability of polymer

${ }^{26}$ A. Dickinson, "Hail", The Polymers, op. cit., 7.

${ }^{27}$ R. Whyatt. Review of Adam Dickinson's Polymers. Lemon Hound 5 (2013). http://lemonhound.com/2013/06/08/rachael-wyatt-on-adam-dickinsons-the-polymers/

${ }^{28}$ A. Dickinson, The Polymers, op. cit., pp. 2-3. 
structures is translated into iterability of social behaviour, as in "Careering", where "championed by pressure-/sensitive graduates" are "performing / the lipophilic ends of somersaults / in matriculating sieves // to lick moisture // off the inside of merit" resins progress and regress in obsessive loops:

make a roof for the people, and the people walk down the street with resin for a roof, and the roof has magnesium in it, and sulphur, and the people walk down the street with resin in their hair, and resins are always falling from the sky to the ground, and birds make a people in the sky, a people of the resin, and the resin composed of the sky, and it composes the sky, and the people walking down the street are the strings of resins. ${ }^{30}$

In "Crossing the Bare Common in Snow Puddles at Twilight", Dickinson engages in a deconstructive unsettling of the organic form which provided an American Transcendentalist Ralph Waldo Emerson and other Romantics before him a conceptual model for grasping the interconnectedness and underlying oneness of all things. The poet takes us to "the DNA structure of the poem," breaking the text of Emerson's Transcendentalist manifesto essay "Nature" into randomly selected clusters of phrases and words, as if trying to reach the organicist foundations of the essay, with its transcendental dream of creating a unifying understanding of the world. What he "excavates" from the text's architechtonics, however, as he himself admits in a letter, are the plastic elements which expose "the text's articulatory nature": "the joining that is also a

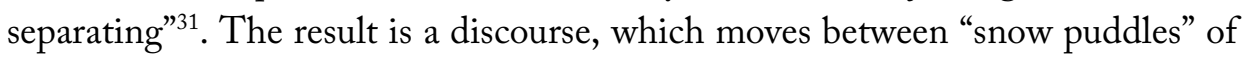
the words cut out from the text, and which seemingly fails to cohere, and yet, the poet's efforts to link the collaged bits with the "polymeric" glue of the connective "and" produces an uncannily poetic effect - of an appearance of sense as well as of an approximated but disrupted wholeness:

Read and write him and what believe

\footnotetext{
${ }^{29}$ Ibid., p. 23.

${ }^{30}$ Ibid., p.19.

${ }^{31}$ A. Dickinson, a private email to the author, September 20, 2016.
} 


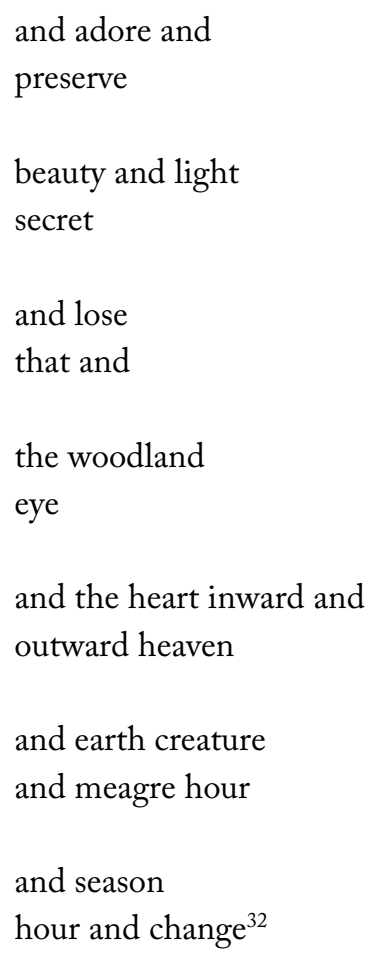

The opening urge "read and write him", followed by the elusive statementcum-question "what believe" which creates un uneasy alliance between belief and doubt, is an invitation to revisit the Romantic intertext but without the epistemological certitude offered by the transcendental metaphysics. The fractured lines "beauty and light / secret // and lose that /and", reminiscent of the modernist experiment, attempt to perform the chaotic force of the sublime as much as they gesture towards our lost faith in nature's redemptive powers, metaphysical secrets and volatile communications. The perforations and ultimate unmaking of Emerson's unifying vision in this peculiar collage questions also the Romantic notion of the organic source of language: here the stitched phrases with no central consciousness to clarify, connect and integrate them suggest that language's discontinuities, contingencies and blanks can no longer be bridged or smoothed out by an over-arching metaphor or conceptual framework. The creative-disruptive plasticity of the poem's form signals further that

\footnotetext{
${ }^{32}$ A. Dickinson, The Polymers, op. cit., p. 84.
} 
"no account of language can escape the aporia of structure and event" ${ }^{33}$ and that organizational and conceptual regimes cannot stop the exploratory activity of language. Adam Dickinson himself admits in an interview that poetry best registers the growing complexity of communication and that it is the activity of language which is "most concerned with the limits of writing" 34 . The poem works to uncover the aporetic logic of figurative discourse, for, as Derrida claims in "White Mythology", metaphor always implies a certain excess, language in "a state of plenitude", pointing to something "superfluous" which cannot be reduced to the sum of its parts. "Something doesn't fit", as noted by Culler ${ }^{35}$, enabling the potential "spillage" of meaning in the process of transference between metaphor's tenor and vehicle ${ }^{36}$. And something doesn't fit here too, and obstinately so - the polysyndetic bonds between Emerson's words obscure and block the transparency and flow of organic metaphors, suggesting that poetry, as the activity most concerned with the limits of writing, takes its power from the tension between the structure and event. This tension in Dickinson's "plastic" poem opens up a cognitive potentiality - a space of inquiry which can help us understand and critically reframe the fluid boundaries and modalities of both biological and cultural realities and selves.

\section{Conclusions}

An American poet-philosopher Wallace Stevens, whose poetry has influenced both Bartczak and Dickinson, argues in one of his poems that "We seek nothing beyond reality / Within it / Everything" ${ }^{37}$. In their deconstructive engagement with the Romantic opposition between organic and synthetic forms, the two poets uncover reality's complex make-up as a set of plastic negotiations

${ }^{33}$ J. Culler. "The Mirror Stage", in: Lawrence Lipking (ed.) High Romantic Argument: Essays for M. H. Abrams.. Ithaca: Cornell University Press, 1981, p. 152.

${ }^{34}$ A. Dickinson. The Polymers: An Interview. Toronto Quarterly: Literary \& Arts Journal 12 (2013). http://thetorontoquarterly.blogspot.com/2013/12/adam-dickinson-polymers-interview.html.

${ }^{35}$ J. Culler, op. cit., p. 161.

${ }^{36}$ J. Derrida. "White Mythology". Margins of Philosophy. Trans. Alan Bass. Chicago: Chicago University Press, pp. 1982, 223, 228, 231.

${ }^{37}$ W. Stevens. "An Ordinary Evening of New Haven", in: The Collected Poems of Wallace Stevens, New York: Vintage Books, 1982. p. 481. 
between aesthetic, rhetorical, social and empirical "protocols" of being. The metaphor of plastic and plasiticity which both poets probe in their innovative volumes shows the osmotic permeability of those protocols which shift between the artificial and natural, the linguistic and the aesthetic, the open and the constrained. Through the playful and mechanical grids of the polymeric structures which inform his volume, Dickinson relates the scientific and the poetic as twin modes of order which structure our world and understanding. In Wiersze organiczne, Bartczak shows that poetry participates in but also queries and unsettles biological, scientific, social and technological ideas of order. Both poets invite contingencies into their forms, creating parallels between plastic and poetry as "translated realities" capable of infinite transformations and heavily "polluted" by other discourses.

Plasticity, as noted by Catherine Malabou, who studied the concept within the neurobiogical context, is a flexibility with a disruptive genius $(2008)^{38}$. I would like to close my argument with Bartczak's poem "Neofita rafinata", in which the Polish poet returns to his definition of poetry as an inclusive, selfrenewing and inquiring "organism" that probes differentiations and barriers:

$\begin{array}{ll}\text { wiersz szuka się poza } & \text { [the poem seeks itself outside] } \\ \text { wiersz że psuje } & \text { [it breaks stuff] } \\ \begin{array}{l}\text { nie koduje nie klaszcze } \\ \text { algorytmiczne nie }\end{array} & \text { [it codes nothing it applauds nothing] } \\ \text { kupczy szyldem nonsensem } & \text { [algorithmically it] } \\ \text { nie kręci nie mrozi lodu } & \text { [does not roll in it freezes no cubes] } \\ \text { nie wstawia ludziom } & \text { [it cuts the crap] } \\ \text { trawi beton i lód. } & \text { [it eats concrete and ice] }{ }^{39}\end{array}$

The opening line "Wiersz szuka się poza" ["the poem seeks itself outside"] captures both Bartczak's and Dickinsons' urge to look for fresh engagements with "the outside", an engagement which shows poetry as a relational network of semantic potentialities, an plastic form created by the very energy of language and its cross-discursive operations.

${ }^{38}$ Catherine Malabou's study of plasticity What Should we Do with Our Brains (New York: Fordham University, 2008), in the context of neurobiology and the functions of the brain, was pointed out to me by Adam Dickinson himself (private email, September 2016).

${ }^{39}$ K. Bartczak, "Neofita rafinata," [angielski przekład: K. Bartczak, P. Ambroży, and K. Majer], Wiersze organiczne, op cit., 13. 


\section{Summary}

The article "In Your Synthesis the Signal Condenses:" The Plastic Poetics of the Contemporary Organic Poem” examines contemporary poets' revisionary engagements with the concept of the organic form. For the analysis I have chosen Adam Dickinson's Polymers (2013) and Kacper Bartczak's Wiersze organiczne [Organic poems] (2015) - the two recent innovative volumes of poetry which approach the notion of organicity via the conceptual metaphor of plastic. The poets take up Roland Barthes' challenge, as formulated in his Mythologies, to engage with the contemporary mythology of plastic and to reclaim for poetry the infinitely transformative potential of synthetic forms. Barthes looks into the "negative reality" of plastic, observing that, "in the hierarchy of the major poetic substances", plastic is perceived as "a disgraced material", a mere substation for the original, "something powerless ever to achieve the triumphant smoothness of Nature" (98). "[M]ore than a substance," the philosopher claims however, "plastic is the very idea of its infinite transformation; as its everyday name indicates, it is ubiquity made visible. And it is this, in fact, which makes it a miraculous substance: a miracle is always a sudden transformation of nature"(97). Using plastic at once as a metaphor and formal frame for their most recent collections, Dickinson and Bartczak experiment with its proliferating, ubiquitous, flocculent and repeated structures, as well as its contradictory nature which thrives in the tension between the natural and the artificial, the original and the imitative, the malleable and resistant, the shaped and shapeless, the colloquial and the scientific. As I argue in the study, Dickinson sees plastic as both outdated and futuristic form, and a curious and ubiquitous language of the contemporary Anthropocene capable of "recreating the world as an alternate and translated reality" (The Polymers). Bartczak, in turn, pulls us into "a translated reality" of his "organic" poems in which highly condensed, opaque and stratified metaphors flaunt their artifice, revealing the obsessive discursive pollutions and transformations of language. Plastic incorporates the inherent paradoxes of organic form in which the notions of completeness, perfection and unity are interwoven with their opposites - temporality, process, contingency and becoming. This doubleness, as evidenced in Bartczak's and Dickinson's poems, proves particularly productive for addressing the aesthetic, ideological and epistemological challenges of contemporaneity

Keywords: contemporary poetry, organic versus synthetic form, plasticity and innovative poetics, Kacper Bartczak, Adam Dickinson, Roland Barthes

\section{Bibliography}

Barthes, Roland. "Plastic". Mythologies. Trans. Annette Lavers. Farrar Strauss \& Girroux, 1972. 97-99.

Bartczak, Kacper. Wiersze organiczne. Łódź: Dom Twórców Literatury, 2015.

Bartczak, Kacper. "Neofita Rafinata." Wiersze organiczne, Łódź: Dom Twórców Literatury, 2015. 13.

Bartczak, Kacper. "Polimer i nic" [Polymer and Nothing]. Wiersze organiczne. Łódź: Dom Twórców Literatury, 2015. 29.

Bartczak, Kacper. "Pieśń tworzyw sztucznych." [The Song of Synthetic Forms]. Wiersze organiczne, Łódź: Dom Twórców Literatury, 2015, pp. 5-9. 
Burwick, Frederick. Introduction. Approaches to Organic Form: Permutations in Science and Culture. Dordrecht, D. Reidel Publishing Company, 1987. ix-xvi.

Coleridge, Samuel, Taylor. "Shakespeare, with Introductory Matter on Poetry, the Drama, and the Stage”, in: The Literary Remains of Samuel Taylor Coleridge. Vol. II.

Collected and Edited by Henry Nelson Coleridge. London: Pickering, 1836, pp. 7-12.

Skurtys, Jakub and Robert Kaczmarski. "Poezja nie jest już liryką". An Interview with

Kacper Bartczak. BiBLioteka: Magazyn literacki.

http://www.biuroliterackie.pl/biblioteka/wywiady/poezja-nie-jest-juz-liryka. Online source.

Culler, Jonathan. “The Mirror Stage," in: Lawrence Lipking (ed.), High Romantic Argument: Essays for M. H. Abrams. Ithaca: Cornell University Press, 1981. Print.

Derrida, Jacques. "White Mythology." The Margins of Philosophy. Trans. Alan Bass. Chicago: Chicago University Press, 1982. 207-272.

Dickinson, Adam. The Polymers. Toronto: Anansi, 2013. Print.

Dickinson, Adam. The Polymers: An Interview. Toronto Quarterly: Literary \& Arts Journal, 2013. http://thetorontoquarterly.blogspot.com/2013/12/adam-dickinson-polymers-interview.html. Online source.

Grimes, Joseph E. The Thread of Discourse. The Hague: Mouton, 1975.

Malabou, Catherine. What Should We Do with Our Brain? Trans. Sebastian Rand. New York: Fordham University, 2008. Print.

Meikle, Jeffrey L. American Plastic: A Cultural History. New Brunswick and London: Rutgers University Press, 1997. Print.

Stevens, Wallace. "An Ordinary Evening in New Haven." The Collected Poems of Wallace Stevens. New York: Vintage Books, 1982. 471-489. Print.

Whyatt, Rachel. Review of Adam Dickinson's Polymers. Lemon Hound 5 (2013).

http://lemonhound.com/2013/06/08/rachael-wyatt-on-adam-dickinsons-the-polymers/. Online source.

Paulina Ambroży, Ph.D., D.Lit./ (dr hab., prof. UAM)

The Faculty of English/ Wydział Anglistyki

Adam Mickiewicz University, Poznań, Poland/ Uniwersytet im. Adama Mickiewicza w Poznaniu 